\title{
Hydrologic responses of a montane riparian ecosystem following cattle use
}

\author{
M. FLENNIKEN, R.R. MCELDOWNEY, W.C. LEININGER, G.W. FRASIER, AND M.J. TRLICA
}

Authors are resource specialist, Larimer County Parks and Open Lands Department, 1800 S. County Rd. 31, Loveland, Colo. 80537; riparian/wetland ecologist, Science Applications International Corporation, 8100 Shaffer Parkway, Suite 100, Littleton, Colo. 80127, professor, Rangeland Ecosystem Science Department, Colorado State University, Fort Collins, Colo. 80523; research hydraulic engineer, USDA, Agricultural Research Service, Fort Collins, Colo. 80526; and professor, Rangeland Ecosystem Science Department, Colorado State University, Fort Collins, Colo. 80523. At the time of the research, both the first and second authors were graduate research assistants, Rangeland Ecosystem Science Department, Colorado State University, Fort Collins, Colo. 80523.

\section{Abstract}

Riparian areas link streams with their terrestrial catchments and decrease water pollution by trapping sediments from upland sources before they reach streams or lakes. Livestock grazing in riparian areas is a controversial practice. If not properly managed, cattle can cause degradation to both the riparian zone and adjacent water body. Vegetative, soil microtopographical, microchannel and hydrograph parameters were measured in a montane riparian community in northern Colorado to quantify the effects of cattle on overland flow and runoff characteristics. Treatments were cattle grazing plus trampling, cattle trampling, mowing, and a control. Water was applied to plots $(3 \mathrm{~m} \times 10 \mathrm{~m})$ at a rate of $100 \mathrm{~mm} \mathrm{hr}^{-1}$ using a rainfall simulator. Concurrently, overland flow was introduced at the upper end of the plots at an equivalent rate of $25 \mathrm{~mm} \mathrm{hr}^{-1}$. A high intensityshort duration grazing treatment was used for the cattle-treated plots. Reduction in vegetation stem density and aboveground biomass by cattle decreased microchannel sinuosity and drainage density. Cattle-treated plots had greater flow velocities and depths in microchannels compared with mowed and control plots. Reduced stem density and aboveground biomass by grazing left fewer obstacles to divert flows, which decreased microchannel sinuosity and drainage density. Flows were concentrated into fewer microchannels with deeper flows. Microchannel characteristics were not significant factors affecting total runoff. Stem density and rainfall intensity were the most important factors in predicting runoff characteristics and total runoff. Results from this study have improved our understanding of flow and runoff processes following cattle use of a riparian ecosystem.

Key Words: runoff, stem density, microchannels, sinuosity, drainage density, rainfall simulation

Suspended sediments can increase water turbidity, transport nutrients and pollutants attached to soil particles, and eventually be deposited in streambeds or lakebeds. Vegetation filter strips (VFS), or bands of planted or indigenous vegetation located between sediment sources and streams, can reduce suspended sediment from overland runoff. The efficiency of VFS to filter

Research was funded by the USDA-ARS, a CSREES Research Grant, and the CSU Agricultural Experiment Station. Authors wish to thank Dennis Mueller, Maxine Cottrell, and Elizabeth Nibarger for their assistance with data collection.

Manuscript accepted 29 Oct. 2000.

\section{Resumen}

Las áreas ribereñas vinculan las corrientes con sus áreas de captación terrestres y disminuyen la contaminación del agua atrapando los sedimentos provenientes de terrenos altos antes de que lleguen a las corrientes o lagos. El apacentamiento de ganado en áreas ribereñas es una practica controversial. Si no es manejada apropiadamente, el ganado puede ocasionar la degradación tanto del área riberña como la del cuerpo de agua adyacente. En una comunidad ribereña montana del norte de Colorado se midieron parámetros vegetativos, microtopográficos del suelo, de microcanales e hidrográficos para cuantificar los efectos del ganado en el flujo superficial y las características del escurrimiento. Los tratamientos fueron: apacentamiento de ganado mas pisoteo, pisoteo de ganado, siega y un control. El agua se aplicó a las parcelas $(3 \mathrm{~m} \times 10 \mathrm{~m})$ a una tasa de $100 \mathrm{~mm}$ $\mathrm{hr}^{-1}$ utilizando un simulador de lluvia. Concurrentemente, el flujo superficial se introdujo en el extremo superior de las parcelas a una tasa equivalente de $25 \mathrm{~mm} \mathrm{hr}^{-1}$. En las parcelas tratadas con ganado se utilizó un sistema de apacentamiento de alta intensidad-corta duración. La reducción en la densidad de tallos y biomasa aérea causada por el ganado disminuyo la sinuosidad de los microcanales y la densidad de drenaje. Las parcelas tratadas con ganado tuvieron velocidades de flujo mas altas y profundas en los microcanales que las obtenidas en las parcelas segadas y control. Una densidad de tallos y biomasa aérea reducidas por el ganado dejan pocos obstáculos para desviar flujos, lo cual disminuye la sinuosidad de los microcanales y la densidad de drenaje. Los flujos se concentraron en unos pocos microcanales con flujos profundos. Las características de los microcanales no fueron factores significativas que afectaran el escurrimiento total. La densidad de tallos y la intensidad de la lluvia fueron los factores mas importantes para predecir las características del escurrimiento y el escurrimiento total. Los resultados de este estudio han mejorado nuestro entendimiento de los procesos de flujo y escurrimiento después de que el ganado uso los ecosistemas ribereños.

sediment depends on surface microtopography, vegetation cover, density and type, slope, and length of the buffer strip (Landry and Thurow 1997). Riparian zones link streams with their terrestrial catchments and serve as natural VFS by trapping sediments from upland sources before they reach streams (Osborne and Kovacic 1993, Daniels and Gilliam 1996, Hairsine 1996). Many models of VFS sediment filtration assume shallow sheet flow (Dillaha 
1989). However, overland flow in grasslands generally does not travel as a uniform sheet, but is concentrated into small channels (microchannels) (Dillaha 1989). Microchannels, for the purpose of this study, were defined as flow paths among the vegetation clumps, normally up to $10-20 \mathrm{~cm}$ wide and carrying water $1-2 \mathrm{~cm}$ deep. In a montane riparian ecosystem, Fernald (1997) evaluated runoff as a factor of vegetation type and microchannel density and documented 1 to 3 primary microchannels in each study plot $(3 \mathrm{~m}$ wide $\mathrm{x} 10 \mathrm{~m}$ long). The density and sinuosity of microchannels may be important determinants of riparian surface hydrology, thus affecting surface runoff rates and sediment delivery to streams.

Livestock grazing effects on infiltration, runoff, and sediment production in uplands have been well studied (Packer 1953, Lusby 1970, Bohn and Buckhouse 1985, Thurow et al. 1986). Grazing intensity, grazing system, timing of grazing, level of defoliation, and amount of trampling have all been shown to affect infiltration, runoff, and sediment yield (Packer 1953, Bohn and Buckhouse 1985, Thurow et al. 1986). Effects of livestock grazing on riparian communities typically involve alteration through soil compaction (Kauffman et al. 1983, Bohn and Buckhouse 1985), defoliation, and physical damage to vegetation (Roath and Krueger 1982, Schulz and Leininger 1990). However, information on specific livestock impacts to a riparian landscape and consequential effects on riparian hydrologic processes is limited. While the results of improper riparian grazing practices on infiltration and runoff have been described elsewhere, little is known about which aspect of livestock use (hoof action or canopy removal) has the greatest effect on riparian surface hydrology.

It was hypothesized that cattle would change runoff and overland flow characteristics by physically affecting both soil and vegetation properties. The objective of this study was to quantify the effects of vegetation mowing, cattle trampling, and cattle grazing plus trampling on soil and vegetation and how these parameters in turn affected runoff and overland flow characteristics through the riparian zone.

\section{Methods}

\section{Site Description}

Research was conducted in a riparian meadow adjacent to Sheep Creek in the Roosevelt National Forest, about $80 \mathrm{~km}$ northwest of Fort Collins, Colo., at an elevation of $2,500 \mathrm{~m}$ (Lat $40^{\circ} 59.725^{\prime}$, Long $\left.105^{\circ} 43.265^{\prime}\right)$. The soils are a sandy loam to clay loam texture stratified with thin layers of sand or clay of the Fluvaquents series (USDA 1980). In places the water table is less than $30 \mathrm{~cm}$ at some time during the spring and summer. There was a heavy organic $\mathrm{O}$ horizon as much as 20 $\mathrm{cm}$ thick in the study site. Soil texture of the surface $7 \mathrm{~cm}$ at the study sites was $36 \%$ sand, $36 \%$ silt, and $26 \%$ clay (clay loam texture). Some mottling was evident, indicating recurrent seasonal soil saturation. The south-facing slopes of the experimental plots ranged from 3 to $5 \%$.

Vegetation at the site was dominated by Kentucky bluegrass (Poa pratensis L.), small-wing sedge (Carex microptera Mack.), water sedge (Carex aquatilis Wahl.), tufted hairgrass (Deschampsia caespitosa (L.) Beauv.), Baltic rush (Juncus balticus Willd.), western yarrow (Achillea lanulosa L.), and marsh marigold (Caltha leptosepala DC.).

\section{Plot Installation and Rainfall Simulator}

Sixteen, $3 \times 10 \mathrm{~m}$ plots ( 25.7 to $28.8 \mathrm{~m}^{2}$ ) were used to evaluate overland flow and runoff in the montane riparian filter strip. Plots were placed perpendicular to Sheep Creek. Plots were paired (3 $\mathrm{m}$ apart) for rainfall simulations where a 'Swanson' large rotating boom rainfall simulator (Swanson 1965) was used to apply water to evaluate runoff and overland flow (Laflen et al. 1991, Frasier et al 1998b). Overland flow was contained within 0.15 $\times 3 \mathrm{~m}$ steel borders $\times 6 \mathrm{~cm}$ driven into the ground along the upper edge and 2 sides of each plot (Pearce et al. 1998). A headwall, flush with the ground surface, was established along the bottom edge of each plot. Steel gutters that lined the headwall collected surface runoff and channeled it through a pre-calibrated flume.

\section{Treatments}

One of 4 treatments was applied to each plot. Treatments included:

1. Grazed plus trampled: To simulate a heavy stocking rate, three, $320-\mathrm{kg}$ heifers were fenced on plots for 8 hours, coinciding with peak feeding times (1600-2000 and 0400-0800 hours).

2. Trampled: Three, $320-\mathrm{kg}$ heifers were fitted with nylon mesh muzzles and fenced on plots for 8 hours (1600-2000 and 0400-0800 hours).

3. Mowed: Plots were mowed with a lawnmower to a $10 \mathrm{~cm}$ stubble height and clippings were removed.

4. Control: Natural vegetation height; no treatment administered.

Feces remained on the cattle-treated plots.

\section{Plot Characterization}

\section{Microtopography}

Microtopography was measured using a 100 -point (10 x $9.6 \mathrm{~cm}$ grid) elevation table (0.6 $\times 2 \mathrm{~m}$ dimension) positioned lengthwise across the center of each plot. Elevation table measurements were made before and after treatments, as well as after the final rainfall simulation. Pin height (mm) above the horizontal table surface was measured with a digital caliper. Microtopography was charcterized by the Revised Universal Soil Loss Equation (RUSLE) method using the maximum range in pin elevations (Renard et al. 1997).

\section{Soil}

Three soil bulk density samples for $0-5$ and $5-10 \mathrm{~cm}$ depths were randomly taken from each plot with a $7.5 \mathrm{~cm}$ diameter soil core sampler before treatment. Soil plugs, taken from directly outside of the plots, were used to refill the holes. Bulk density was resampled on the grazed and trampled plots following treatment. The soil cores were composited by plot and depth class. Three, $50 \mathrm{mg}$, air-dried subsamples per plot were later combusted at $600^{\circ} \mathrm{C}$ for 4 hours to determine organic matter (OM) content. Gravimetric soil moisture in the top $10 \mathrm{~cm}$ of soil was determined with 3 samples taken from each plot just prior to pre-conditioning, and again before the post-treatment rainfall simulation. Each soil moisture sample was weighed, dried in a microwave oven in $5 \mathrm{~min}$ increments until less than a $0.5 \mathrm{~g}$ change in weight occurred, and then reweighed.

\section{Vegetation}

Vegetation density (stems $\mathrm{m}^{-2}$ ) was measured at ground level and categorized by class (i.e., grasses, forbs, sedges, and Baltic rush) using a $10 \times 10 \mathrm{~cm}$ quadrat. Before all treatments and again after the grazed and trampled treatments, the number of stems in 10 randomly placed quadrats within the lower $2 / 3$ of each plot was recorded. Stem width at ground level was measured at 10 random locations within the lower $2 / 3$ of each plot (i.e., 10 stems of each vegetation class were measured per plot).

Vegetation was clipped to ground level in a $1 / 8 \mathrm{~m}^{2}$ circular plot and bagged to estimate aboveground biomass. Five bio- 
mass samples were randomly taken in each plot before and after treatment. The trampled treatment was only sampled before treatment. Samples were dried in a forced draft oven for 72 hours at $50^{\circ} \mathrm{C}$ before weighing.

\section{Microchannels}

Microchannel sinuosity was indexed for each plot as the ratio of channel length to the straight line distance between 2 fixed points approximately $1 \mathrm{~m}$ apart (George and Sidle 1995). The closer the sinuosity values are to 1 , the straighter the flow paths. Microchannel sinuosity was measured within 10 random grid sections per plot. Drainage density $\left(\mathrm{m} \mathrm{m}^{-2}\right)$ was calculated by measuring the total length of microchannels within a plot divided by the plot area (adapted from Schumm and Hadley 1959). Flow depths in microchannels were measured during equilibrium runoff with a ruler to the nearest $\mathrm{mm}$ at 6 random locations, both downslope and cross-slope within each plot during the simulation run.

\section{Rainfall Simulations}

Two rainfall simulation runs, about 24 hours apart, were made on each plot pair; one before (pre-treatment) and one after (post-treatment) treatments were applied.

Water was applied to the plots at an approximate rate of $100 \mathrm{~mm}$ hour $^{-1}$ for a total run time of about $100 \mathrm{~min}$. This rate was equivalent to approximately double that of a 100 year-1 hour rainstorm event and was chosen based on studies by Pearce et al. (1998). The rate of application was also selected to insure there would be sufficient amount of water to exceed the infiltration rate. Total quantities of water applied were measured with 6 rain gages placed within each plot. Actual simulation intensities were recorded for each plot pair with an $8 \mathrm{~cm}$ diameter volumetric raingage equipped with a bubble gage pressure transducer. Concurrent with rainfall simulation, overland flow was simulated by spraying water onto a $3.0 \mathrm{x}$ $0.6 \mathrm{~m}$ tilted input tray at the top of each plot at the equivalent rate over the entire plot of $25 \mathrm{~mm} \mathrm{hour}^{-1}$. Runoff was measured at the outlet of each plot with a precalibrated critical depth flume and data were recorded by bubble gage pressure transducer recorders in 1 min intervals.

\section{Pre-treatment Rainfall Simulation}

Plots were preconditioned 24 hours before treatments using the rainfall simulator. The preconditioning was done to minimize soil moisture variability among plots and to increase the soil's vulnerability to compaction (Warren et al. 1986). A dye tracer was applied as a line source at 2 locations (3 and $6 \mathrm{~m}$ downslope from the top of plot) across each plot to allow identification of the water front advancement and flow paths down the plots (Fernald 1997). All runoff events were recorded and timed on video to allow re-examination of channel locations at a later date and to determine the peak channel velocity of the water movement downslope. Strings stretched across each plot on a $50 \times 50 \mathrm{~cm}$ grid were used to estimate water velocity through the microchannels as the dye moved downslope. Immediately after the preconditioning event, the primary microchannels as delineated by the dye tracer were spray painted and photographed.

\section{Post-Treatment Rainfall Simulation}

Following treatments, rainfall was simulated again over the paired plots. Concurrent with rainfall application, overland flow was again introduced at the top of the plot at the equivalent rate of $25 \mathrm{~mm}$ hour $^{-1}$ over the entire plot. During the rainfall simulation, a dye tracer was again applied as a line source across the plots at the same locations and flow rates and paths were recorded on video and timed. Immediately after the simulation, the primary microchannels were again delineated with spray paint and photographed.

\section{Runoff Hydrograph}

A runoff hydrograph is a graphical representation of a runoff event showing the change in runoff rate through time. Hydrographs can be divided into their constituent parts for analysis of treatment effects (Simanton et al. 1991, Frasier et al. 1998a, 1998b). Hydrograph components analyzed in this study included time to runoff initiation, slope of the rising limb, time to equilibrium, equilibrium runoff, slope of the falling limb, and total runoff.

Breakpoints between hydrograph segments were estimated using an iterative least squares regression process developed by Brakensiek et al. (1979) for analysis of precipitation data. Regression coefficients from rising limb and falling limb trend lines were considered the slopes of these hydrograph components. Time to equilibrium runoff was determined when a constant rate of flow occurred for 2 consecutive recorder readings (4 min).

Weather conditions and slight differences among spray nozzles caused varying application rates, even among paired simulation plots. To compensate for this, accumulated runoff values were normal- ized in 1 min intervals into percentages [(runoff rate/total application rate) $\mathrm{x}$ (100)] (Frasier et al. 1998b). Accumulated runoff after 60 min of simulation was also evaluated for treatment effects. The 60 min time frame was selected because it was common to all simulations.

\section{Experimental Design}

A randomized complete block (RCB) design was used for this experiment. There were 4 treatments (grazed plus trampled, trampled, mowed, and control) and 4 blocks. Soil and vegetation responses were included as covariates to explore their relationships with treatment effects. Multiple regression models were constructed for microchannel sinuosity, drainage density, flow depths, accumulated runoff, time to runoff initiation, slope of the rising limb, time to equilibrium, equilibrium runoff, and slope of the falling limb using forward and stepwise selection processes. The independent variables for these models included: slope, plot area, stem density by vegetation class, overall stem density, sinuosity, drainage density, flow depths, rainfall intensity, spraybar intensity, aboveground biomass, soil organic matter, soil bulk density, soil moisture, surface roughness, ground cover, stem basal widths, and pre-treatment values for each variable. Unless stated otherwise, significance was determined at $\mathrm{P} \leq 0.10$. Data were analyzed using SAS ${ }^{\circledR}$ for Windows ${ }^{\circledR}\left(\right.$ SAS $^{\circledR}$ 1996).

\section{Results and Discussion}

\section{Variables not affected by cattle treatments \\ Microtopography}

There were no significant differences among treatments for random surface roughness using the RUSLE method (Flenniken 1999, McEldowney 1999). The large amount of organic matter on the plots may have acted like a sponge and was not altered by the treatments. The connectivity of microtopography may be a more important characteristic in riparian hydrology than variations in surface roughness (Fernald 1997, Frasier et al. 1998b). The connectivity of microtopographical soil surface features may directly influence flows through microchannels and subsequent runoff rates.

\section{Soil moisture and organic matter}

Soil moisture and soil organic matter estimates for the top $10 \mathrm{~cm}$ of soil were 
Table 1. Summary data for selected variables for each of the 4 treatments applied to a montane riparian community.

\begin{tabular}{|c|c|c|c|c|}
\hline \multirow[b]{2}{*}{ Parameter } & \multicolumn{4}{|c|}{ TREATMENT } \\
\hline & Control & Mowed & Trampled & Grazed \\
\hline \multicolumn{5}{|l|}{ POST-TREATMENT } \\
\hline Plot area $\left(\mathrm{m}^{2}\right)$ & $28.8 b$ & $27.3 \mathrm{ab}$ & $26.8 \mathrm{a}$ & $27.4 \mathrm{ab}$ \\
\hline Slope $(\%)$ & $3.8 \mathrm{a}$ & $3.6 \mathrm{a}$ & $4.2 \mathrm{a}$ & $3.8 \mathrm{a}$ \\
\hline Rainfall intensity (mm hour ${ }^{-1}$ ) & $102 b$ & $89 \mathrm{a}$ & $89 a$ & $102 b$ \\
\hline Spraybar runon intensity ( $\mathrm{mm} \mathrm{hour}^{-1}$ ) & $25.7 \mathrm{a}$ & $26.6 \mathrm{a}$ & $27.4 \mathrm{a}$ & $27.8 \mathrm{a}$ \\
\hline Soil moisture $(\%)$ & $36 \mathrm{a}$ & $36 \mathrm{a}$ & $36 \mathrm{a}$ & $36 \mathrm{a}$ \\
\hline Soil organic matter $0-5 \mathrm{~cm}(\%)$ & $19.3 \mathrm{a}$ & $20.6 \mathrm{a}$ & $19.5 \mathrm{a}$ & $22.4 \mathrm{a}$ \\
\hline Soil organic matter $0-10 \mathrm{~cm}(\%)$ & $10.1 \mathrm{a}$ & $10.8 \mathrm{a}$ & $12.2 \mathrm{a}$ & $11.3 \mathrm{a}$ \\
\hline Bulk density $0-5 \mathrm{~cm}\left(\mathrm{~g} \mathrm{~cm}^{-3}\right)$ & $0.6 \mathrm{a}$ & $0.6 \mathrm{a}$ & $0.7 \mathrm{a}$ & $0.6 \mathrm{a}$ \\
\hline Bulk density $0-10 \mathrm{~cm}\left(\mathrm{~g} \mathrm{~cm}^{-3}\right)$ & $0.9 \mathrm{a}$ & $0.9 \mathrm{a}$ & $0.9 \mathrm{a}$ & $0.9 \mathrm{a}$ \\
\hline Stem density (\# stems $\mathrm{m}^{-2}$ ) & $5275 \mathrm{bc}$ & $5525 \mathrm{c}$ & $4650 \mathrm{~b}$ & $3300 \mathrm{a}$ \\
\hline Litter ground cover $(\%)$ & $63 a$ & $65 \mathrm{a}$ & $61 \mathrm{a}$ & $62 \mathrm{a}$ \\
\hline Aboveground biomass $\left(\mathrm{kg} \mathrm{ha}^{-1}\right)$ & $2330 b$ & $1725 \mathrm{a}$ & $*$ & $924 a$ \\
\hline Microchannel sinuosity & $1.24 \mathrm{c}$ & $1.17 \mathrm{~b}$ & $1.04 \mathrm{a}$ & $1.04 \mathrm{a}$ \\
\hline Drainage density $\left(\mathrm{m} \mathrm{m}^{-2}\right)$ & $2.1 \mathrm{~b}$ & $2.4 \mathrm{~b}$ & $1.7 \mathrm{a}$ & $1.7 \mathrm{a}$ \\
\hline Flow depth in microchannels $(\mathrm{mm})$ & $18 \mathrm{a}$ & $24 \mathrm{ab}$ & $26 b$ & $32 \mathrm{c}$ \\
\hline Accumulated runoff after $60 \mathrm{~min}(\%)$ & $45.2 \mathrm{ab}$ & $35.0 \mathrm{a}$ & $48.8 \mathrm{~b}$ & $67.3 \mathrm{c}$ \\
\hline Time to runoff initiation* $(\min )$ & $14.3 \mathrm{~b}$ & $22.2 \mathrm{c}$ & $12.8 \mathrm{ab}$ & $9.0 \mathrm{a}$ \\
\hline Slope of the rising limb* $(\%)$ & $8.4 \mathrm{a}$ & $9.0 \mathrm{ab}$ & $7.0 \mathrm{a}$ & $16.6 b$ \\
\hline Time to equilibrium runoff ( $\mathrm{min}$ ) & $20.9 b$ & $34.4 \mathrm{~d}$ & $28.3 \mathrm{c}$ & $15.8 \mathrm{a}$ \\
\hline Slope of the falling limb - & $6.7 \mathrm{ab}$ & $-7.8 \mathrm{a}$ & $-5.3 b c$ & $-5.1 c$ \\
\hline
\end{tabular}

Different letters following means in a row indicate significance at $\mathrm{p} \leq 0.10$. An $*$ indicates missing data.

not different among treatments (Table 1). However, soil moisture did vary by block; lower soil moisture occurred near the upper part of the riparian meadow and increased with proximity to Sheep Creek.

\section{Bulk density}

Soil bulk densities for the $0-5 \mathrm{~cm}$ and 5$10 \mathrm{~cm}$ soil depths were not affected by cattle activity (Table 1). In the top $5 \mathrm{~cm}$ of soil, bulk density ranged from 0.47 to $0.81 \mathrm{~g} \mathrm{~cm}^{-3}$; while in the $5-10 \mathrm{~cm}$ depth class, bulk density ranged from 0.65 to $1.14 \mathrm{~g} \mathrm{~cm}^{-3}$. The large amount of soil organic matter, the clay loam soil texture, and the large amount of litter cover all may have contributed to mitigating compaction effects by trampling (AbdelMagid et al. 1987, Wheeler et al. 2002).

\section{Basal Widths}

Basal widths did not vary among treatment. However, basal widths among vegetation classes were different, with forbs having the greatest average basal widths $(4.7 \mathrm{~mm})$. Basal widths of sedges, grasses, and Baltic rush were not significantly different from each other $(2.8,1.4$, and 1.1 $\mathrm{mm}$, respectively). Average values of stem basal widths were similar to widths measured by Fernald (1997) at the site, with the exception of Baltic rush, which he measured to be wider than grasses.

\section{Variables affected by cattle treat- ments \\ Aboveground Biomass}

Aboveground biomass was $58 \%$ less on grazed plots than on control plots (Table 1). There were significant differences in aboveground biomass for the mowed, grazed, and control plots. The decrease in aboveground biomass on grazed compared with control plots represents the amount of vegetation consumed by grazing or removed via cattle trampling. As a result of logistical constraints, the trampled plots were not sampled for aboveground biomass.

\section{Stem Density}

There was a $40 \%$ decrease in stem density following cattle grazing, as compared to the control (Table 1). The grazed plus trampled treatment had the lowest average stem density, because cattle removed stems both by pulling up stems with grazing and through hoof shear (Kauffman et al. 1983, Abdel-Magid et al. 1987). Stem density for the trampled treatment was higher than that for the grazed treatment, probably because there was only hoof shear and not the grazing component with the trampled treatment. Specifically, forb stem densities were decreased by $50 \%$ on both trampled and grazed plus trampled treatment, as compared with the control. Grass stem densities were reduced approximately $40 \%$ on grazed plots as compared with control plots.
Stem density was a very important variable that affected microchannel sinuosity, drainage density, flow depth, accumulated runoff, time to runoff, slope of the rising limb of the hydrograph, time to equilibrium runoff, and the slope of the falling limb of the hydrograph (Table 2). The significant reduction in stem density following both types of cattle treatments subsequently impacted microchannel and runoff characteristics.

\section{Microchannel Characteristics}

All microchannel characteristics, sinuosity, drainage density, flow depth, and flow velocity, were significantly affected by decreased stem density on cattle-treated plots. However, other variables were also important and will be discussed specifically below. While microchannel characteristics could have potentially affected runoff characteristics, they were not significant in prediction equations. Rather, stem density was a more important predictor variable (Table 2).

\section{Microchannel Sinuosity}

Water flowed down the plots in microchannels, though sheetflow occurred between these microchannels for short distances. Similar intermittent sheetflow between flow lines was observed in laboratory experiments by Mosley (1972). There were no differences among plots for pre-treatment sinuosity. Following cattle treatments, however, the microchannels were straightened. There were no differences in microchannel sinuosity between the trampled and grazed plus trampled treatments, indicating that hoof action was primarily responsible for straightening microchannels. The mowed treatment was intermediate in sinuosity to the control treatment and the cattle-treated plots (Table 1).

Multiple regression analysis was used to identify important variables that correlated with and presumably affected post-treatment microchannel sinuosity data. The important independent variables selected by both stepwise and forward regression analyses were forb stem density and grass stem density $\left(r^{2}=0.78\right)$ (Table 2). Prosser et al. (1995) showed that root stocks and individual submerged stems deflected water flows. Although no other references could be found that related stem density to microchannel sinuosity, aboveground biomass (which is a function of stem density) can serve as a barrier to sediment transport by causing overland flow to move in a slower, more tortuous path (Thurow et al. 1986). Abrahams et al. (1994) reported 
Table 2. Prediction equations for various response variables affected by treatments.

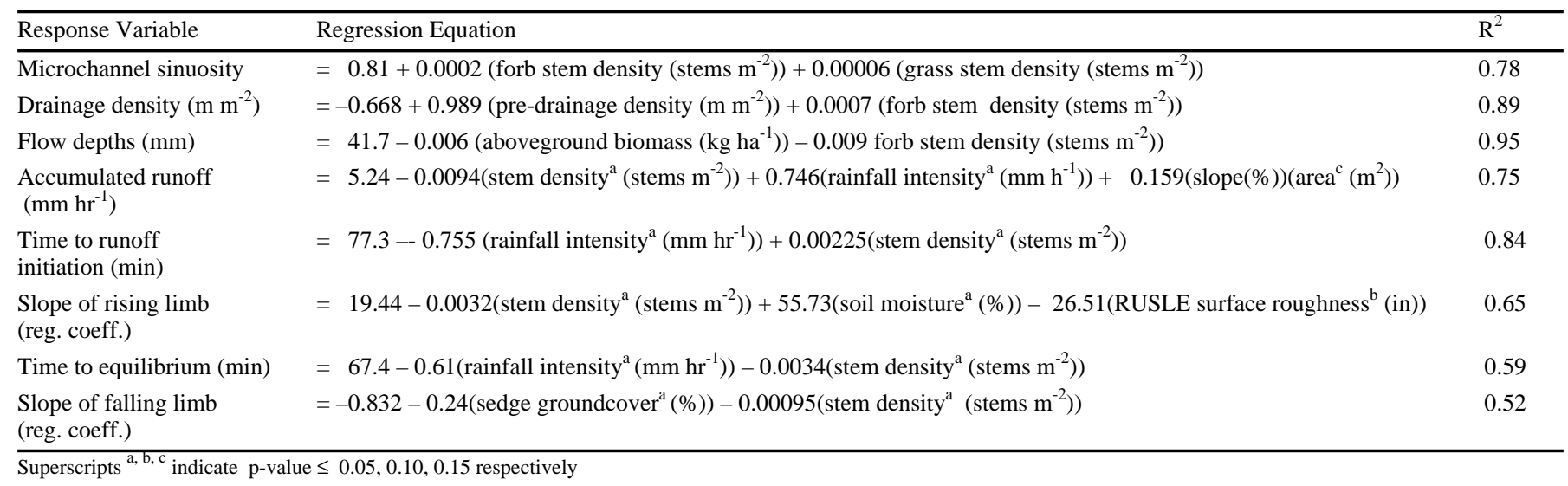

that $69 \%$ of the variability in resistance to overland flow (using the Darcy-Weisbach friction factor $(f)$ ) was accounted for by basal plant stems and litter cover on an Arizona grassland. With fewer stems to act as barriers to downslope water flow, sinuosity was reduced in their study.

Forb and grass stems may have been influential in directing and concentrating flows. Forbs had the largest stem basal widths of all vegetation classes, possibly making them more influential in directing microchannel flows and were more important if lost through trampling. A reduction in forb and grass stem density in cattletreated plots resulted in fewer obstacles to divert flows, and microchannel sinuosity was lower.

In studies of geomorphic processes on small-scale channels in Utah, George and Sidle (1995) observed that many of these small channels functioned like gullies in flow dynamics, partly as a result of their low sinuosity. A gully is a relatively deep, vertical-walled channel. It is possible that the low sinuosity for the cattle-treated plots may have resulted in the microchannels more closely resembling gullies rather than channels. If these microchannels behave more like gullies, greater erosive forces on the channel walls and more movement of sediment during overland flow might be expected, rather than flows characteristic of other types of channels. Future studies might involve closer examination of microchannel dimensions.

\section{Drainage Density}

There was no difference in drainage density among plots before treatment. This lack of difference allowed for comparison of drainage density between post-treatment cattle plots and pre-treatment control and mowed plots. Cattle-treated plots had lower drainage densities than either mowed or control plots (Table 1). Average drainage density was $19 \%$ lower on cattle-treated plots than on control plots, and $26 \%$ lower than on mowed plots. Visual examination of plots before and after treatment confirmed this finding (Flenniken 1999).

The prediction equation that best described drainage density following cattle treatments included the independent variables pre-drainage density and forb stem density (Table 2). The model accounted for $89 \%$ of the variation in drainage density among treatments, and indicated that pretreatment drainage density and forb stem density had significant influences on the final measure of drainage density. Obviously, pre-treatment drainage density would be an important determinant of posttreatment drainage density. Since forbs had the greatest stem basal widths of all the measured vegetation classes, their stems acted as barriers in routing water flow. The decrease in forb stem density on cattletreated plots from hoof shear resulted in fewer barriers for water diversion and may have caused straightening of the microchannel network.

\section{Flow Depths in Microchannels}

Post-treatment downslope water flow depths in microchannels were affected by the treatments. Flow depths in microchannels of the grazed plus trampled treatment were the greatest of the 4 treatments; nearly $80 \%$ deeper than in the control treatment (Table 1). There were no differences in downslope flow depths between trampled and mowed treatments, or between mowed and control treatments. The high rainfall rate $\left(\sim 100 \mathrm{~mm} \mathrm{hour}^{-1}\right)$ and overland flow ( $\left.25 \mathrm{~mm} \mathrm{hour}^{-1}\right)$ applied to the plots may have overtopped microtopographical elevations.

The prediction equation for post-treatment downslope flow depths in microchannels included the independent variables of aboveground biomass and forb stem density (Table 2). The model accounted for $95 \%$ of the variability in flow depths among treatments. A reduction in aboveground biomass and forb stem density from grazing concentrated water into straightened microchannels. Increased runoff and decreased drainage density following cattle treatments also concentrated water into fewer microchannels, resulting in deeper downslope flow depths in the remaining microchannels.

\section{Flow Velocities}

No significant differences in flow velocity existed among the 4 treatments. The leading edge microchannel flow velocity was $0.05 \mathrm{~m} \mathrm{sec}^{-1}$ on cattle-treated plots, and $0.03 \mathrm{~m} \mathrm{sec}^{-1}$ on the control and mowed plots. A small sample size is partly responsible for these results, as the videotapes only allowed for estimation of a single velocity on each of the treatment plots. In future studies, this problem could be alleviated by direct measurement of flow velocities in the field utilizing a flow meter or similar method.

\section{Runoff characteristics}

On first assessment, it was anticipated that changes in soil characteristics (soil moisture, bulk density, and infiltration rate) would greatly influence runoff characteristics. However, it was not a soil phenomenon but rather changes in surface phenomenon of both vegetation and microchannel characteristics that most significantly influenced runoff.

\section{Accumulated Runoff}

Despite no significant differences among treatments for initial infiltration rates, the runoff hydrographs indicated 
that differences in accumulated runoff did exist among treatments (McEldowney 1999). These differences were especially evident during the early stages of runoff and contributed to the greater percentage of applied water that ran off of the grazed plots, when compared with the trampled, mowed, or control plots (Table 1). Results also indicated that equilibrium runoff was not greatly influenced by the treatments, suggesting that these early periods of runoff may provide more insight into the effects of various types of surface disturbances on overland flow.

For example, Packer (1953) determined that simulated trampling within the Boise River watershed in Idaho increased overland flow in 2 community types with initial ground cover values less than 90 to $95 \%$. In a 10 year study conducted near Grand Junction, Colo., Lusby (1970) noted grazed watersheds had 30\% more runoff than did ungrazed watersheds. He believed that increased runoff was directly related to the amount of bare soil. Heavy continuous grazing on small mixed shortgrass and midgrass prairie watersheds in South Dakota resulted in higher runoff rates than from moderately and lightly grazed watersheds (Hanson et al. 1970). Total runoff was greater from heavily grazed shortgrass prairie as compared to lightly grazed areas in eastern Colorado (Frasier et al. 1995).

The parameters that best predicted the amount of accumulated runoff after 1 hour were stem density, rainfall intensity, and a slope-gradient by area-interaction. The prediction model for accumulated runoff shown in Table 2 explained $75 \%$ of the measured variability. Inclusion of rainfall intensity and the topographic interaction between slope and area in this regression model was expected, as these variables are common parameters in many models of runoff, erosion, and water quality (Schreiber and Kincaid 1967, Dunne and Leopold 1978, Hairsine et al. 1992, Renard et al. 1997). Reduced stem density on the grazed treatments probably allowed more water to runoff of those plots and has not been included in most runoff models.

Vegetation height was not measured in this study, but was visually homogenous throughout the study area prior to treatments. In other studies, vegetation height was an important parameter for runoff prediction (Prosser et al. 1995, Clary et al. 1996). Visual similarity in vegetation height between the control and trampled treatments suggests that vegetation on these plots was overtopped by the high intensity of simulated rainfall (Abt et al.
1993, Pearce 1995, Prosser et al. 1995), and facilitated the movement of water off of these plots.

\section{Time to Runoff Initiation}

The treatments did affect the length of time required for runoff to begin, and ranged from $9 \mathrm{~min}$ on the grazed treatment to 22 min on the mowed treatment (Table 1). These values were similar to runoff initiation times reported by Frasier et al. (1998b) and Fernald (1997). Multiple regression analysis revealed that rainfall intensity and stem density accounted for $84 \%$ of the total measured variability in the prediction of time to runoff initiation (Table 2).

\section{Rising Limb of the Hydrograph}

The slope of the rising limb of the hydrograph was steep for the grazed treatment (Table 1). This value was not different from the mowed treatment, but was greater than the trampled and control treatments. The slopes of the rising limb for the mowed, trampled, and control treatments were not different from one another. These slopes (regression coefficients) for the rising limb trendline of the hydrograph were generally higher than those found by Frasier et al. (1998b). Simulation intensity was $40 \mathrm{~mm}$ hour $^{-1}$ greater than those used by Frasier et al. (1998b) and this was probably the reason for the difference. The rate of change of the rising limb of the runoff hydrograph is an indicator of the amount of depression storage and infiltration (Mohamoud et al. 1990, Frasier et al. 1998b). During the rising limb, depression storage has often been assumed to be completely filled (Mohamoud et al. 1990). As rainfall continues, the successive overtopping of depressions makes more water available for runoff until the majority of the plot area is contributing to runoff. A smaller, or less steep, slope of the rising limb corresponds to slower runoff rates and likely indicates the degree of connectivity among surface depressions.

Antecedent soil moisture was the most important parameter for the prediction of the slope of the runoff hydrograph rising limb (Table 2). Stem density and the RUSLE surface roughness measurement improved the prediction model and together these 3 parameters explained $65 \%$ of the variability in the prediction of the slope of the rising limb of the hydrograph. Antecedent soil moisture can affect infiltration rates and, consequently, surface runoff (Branson et al. 1981). The soil moisture gradient from lower soil moisture along the upper portion of the riparian meadow to much higher soil moisture near Sheep Creek helped to explain its importance in the regression equation developed from these data (McEldowney 1999). At the Walnut Gulch Experimental Watershed in southern Arizona, Schreiber and Kincaid (1967) concluded that antecedent soil moisture was not as important as plant parameters in runoff prediction. Inclusion of random roughness in our prediction model during this early stage of runoff indicated that the volume of water applied had not yet completely overwhelmed microtopographical features, and emphasized the importance of microrelief on the early stages of overland flow initiation.

\section{Time to Equilibrium Runoff}

The time required to reach equilibrium runoff was affected by the treatments, and ranged from $16 \mathrm{~min}$ for the grazed treatment to $35 \mathrm{~min}$ for the mowed treatment. All treatments were significantly different from one another (Table 1). Rainfall intensity and stem density strongly influenced the time needed to reach equilibrium runoff. These 2 parameters accounted for $59 \%$ of the total variability for the time to runoff equilibrium (Table 2). Both rainfall intensity and stem density have already been discussed, and were applicable to the prediction model for time to equilibrium runoff for reasons stated earlier.

\section{Slope of the Falling Limb of the Hydrograph}

Significant differences were found between the 2 cattle treatments and the mowed treatment for the slope of the falling limb of the hydrograph (Table 1). However, the slope of the falling limb for the trampled treatment was not different from the control. A potential reason for this was that the tall vegetation on the control and trampled treatments was pushed over by the intense rainfall or cattle trampling, creating a surface conducive to runoff (Abt et al. 1993, Pearce 1995, Prosser et al. 1995). Both the falling limb of the trampled and control treatments were fairly steep as this water ran off rapidly once the simulator was turned off. The runoff hydrograph falling limb for the trampled and control treatments did not decline as rapidly as that from the mowed treatment, nor as slowly as that from the grazed treatment.

The runoff hydrograph falling limb represents the portion of the applied water on the plot surface that only runs off once the simulator is turned off and rainfall ends. Therefore, the falling limb can be used as an indicator of water storage on the sur- 
face (Foster 1971, Dunne and Leopold 1978, Rogers and Singh 1986) and in the soil. More water moved off the cattletreated plots and did not infiltrate into the soil, which contributed to the flattened slopes of the falling limb of the cattletreated plots in the runoff hydrograph (Table 1).

The prediction model for the slope of the falling limb of the hydrograph was best described by stem density and sedge ground cover $\left(r^{2}=0.52\right)$ (Table 2). Sedge ground cover did not differ among treatments, but was very different among blocks. The regression equation indicated that as sedge ground cover increased, the slope of the falling limb of the hydrograph was greater.

\section{Summary and Conclusions}

This study improves our understanding of flow and runoff processes following cattle use of montane riparian ecosystems. Vegetation stem density was greatly reduced on cattle-treated plots and was a major factor that affected flow characteristics. Studies by Rogers and Schumm (1991) showed that vegetation disrupts overland flow by both concentrating and deflecting flow around individual vegetation obstructions. Specifically, forb stem density appeared to be the most influential vegetation class affecting the various flow parameters in the current study. Forbs had the greatest basal widths of stems and probably affected downslope flows by diverting water. Forbs were also possibly more susceptible to cattle trampling than graminoids.

Cattle grazing and trampling had a significant effect on flow characteristics through decreased microchannel sinuosity and drainage density, and increased flow depths. Water flowed down the plots in small channels, though sheetflow did occur between these microchannels for short distances with high water application rates. Cattle grazing and trampling straightened the microchannels, and this decreased sinuosity resulted in decreased drainage density. On cattle-treated plots, water concentrated in fewer, straighter microchannels, resulting in deeper flow depth and possibly increased flow velocities. With less ground cover, concentrated flow increases flow velocity and depth (Rogers and Schumm 1991). Velocity is a function of channel gradient and roughness, so with decreased sinuosity and greater gradient following cattle treatments as well as decreased roughness from stem density, greater flow velocities should occur. Control and mowed plots had more sinuous flow paths compared with cattle-treated plots because there was no decrease in stem density, thus more obstacles were present at the soil surface to route water around.

Changes in vegetation and flow characteristics may have consequences for erosion and effectiveness of riparian filters. Densely covered grasslands provide resistance, expressed as a threshold of shear stress, to erosion by overland flow. Most shear stress is exerted on individual plant stems and dense bunches of grasses (Prosser et al. 1995). Dillaha et al. (1989) suggested that unless concentrated flow is minimized in vegetation filter strips (VFS), it is unlikely the VFS will be very effective in controlling nonpoint source pollution.

Stem density was also one of the most important factors affecting runoff. Cattle grazing reduced total stem density, which reduced this friction component and created a surface less resistant to overland flow. These results suggest that closely monitored stem density could help to create an optimal situation for water retention and reduction of overland flow. It is important to note that the high water application rate used in this study caused the plots to be almost completely inundated with water. At lower levels of inundation, stem density might have less influence on runoff.

Abiotic factors that affected runoff prediction were rainfall intensity, slope, plot area, and soil moisture. Rainfall intensity was especially important for runoff initiation, as expected. High intensity-high frequency cattle grazing primarily impacted the initial and final stages of runoff. Runoff initiation was more rapid and leveled off quickly on grazed plots when compared with control plots. These differences resulted in greater accumulated runoff from grazed plots.

In this study, high intensity-high frequency cattle grazing created a more uniform flow regime across the trampled and grazed treatments. The microchannels became wider and tended to be less sinuous. Because the effectiveness of riparian buffers is often dependent on uniform flow, careful management of cattle along the upper edges of a riparian buffer may help to create a more uniform flow distribution entering the buffer, which could lead to improved sediment filtration.

This study was designed to better understand the effect of the cattle grazing and trampling on the factors that affect runoff in a riparian zone. The study was designed to maximize this effect, and it would be expected that with normal management practices the impact of the cattle would be less than we measured. It was a study at one place and time and results would be expected to apply to other sites with similar soils and vegetation composition.

Further research of flow processes will better allow us to quantify the effects that cattle have on riparian surface hydrology and sediment delivery to streams. Additionally, studies such as this one may be important in erosion prediction models or the development of a riparian-specific erosion model. Future studies in different riparian communities using lower simulation rates should be conducted to corroborate or refute the results presented here, and to expand the applicability of these findings. The effects of different grazing intensities and timing of grazing disturbance on stem density, microtopography, and runoff hydrographs in various riparian ecosystems also should be quantified.

\section{Literature Cited}

Abdel-Magid, A.H., M.J. Trlica, and R.H. Hart. 1987. Soil and vegetation responses to simulated trampling. J. Range Manage. 40: 303-306.

Abrahams, A.D., A.J. Parsons, and J. Wainwright. 1994. Resistance to overland flow on semiarid grassland and shrubland hillslopes, Walnut Gulch, southern Arizona. J. Hydrol. 156:431-446.

Abt, S.R., W.P. Clary, and C.I. Thornton. 1993. Sediment entrapment in vegetated streambeds. pp. 75-91. In Preserving Our Environment-The Race Is On. Proc. Inter. Erosion Control Assoc., Conference XXIV, Feb. 23-26, 1993. Indianapolis, Ind.

Bohn, C.C. and J.C. Buckhouse. 1985. Some response of riparian soils to grazing management in northeastern Oregon. J. Range Manage. 38:378-381.

Brakensiek, D.L., H.B. Osborn, and W.J. Rawls. 1979. Field manual for research in agricultural hydrology. USDA-SEA Agr. Handb. No. 224. Washington, D.C., 548 p.

Branson, F.A., G.F. Gifford, K.G. Renard, and R.F. Hadley. 1981. Rangeland Hydrology. Kendall/Hunt Publishing. Dubuque, Iowa. 340 p.

Clary, W.P., C.I. Thornton, and S.R. Abt. 1996. Riparian stubble height and recovery of degraded streambanks. Rangelands 18:137-140.

Daniels, R.B. and J.W. Gilliam. 1996. Sediment and chemical load reduction by grass and riparian filters. Soil Sci. Soc. Amer. J. 60:246-251.

Dillaha, T.A. 1989. Water quality impacts of vegetative filter strips. ASAE Paper No. 89-2043. St. Joseph, Mich. 9 p. 
Dillaha, T.A., R.B. Reneau, S. Mostaghimi, and D. Lee. 1989. Vegetative filter strips for agricultural nonpoint source pollution control. Trans. ASAE 32:513-519.

Dunne, T. and L.B. Leopold. 1978. Water in Environmental Planning. W.H. Freeman and Co. New York. 818 p.

Fernald, S. 1997. Microchannel flow networks and plot scale runoff dynamics in riparian area overland flow. Ph.D. Diss. Colorado State Univ. Fort Collins, Colo.

Flenniken, M. 1999. Flow characteristics and sediment movement in a montane riparian ecosystem. M.S. Thesis. Colorado State Univ. Fort Collins, Colo.

Foster, G.R. 1971. The overland flow process under natural conditions. pp. 17-185. In: E.J. Monke (ed.) Biological Effects in the Hydrological Cycle. Proc. Third Int. Seminar for Hydrol. Professors. July 18-30, 1971. Purdue Univ. West Lafayette, Ind.

Frasier, G.W., R.H. Hart, and G.E. Schuman. 1995. Rainfall simulation to evaluate infiltration and runoff characteristics of a shortgrass prairie. J. Soil and Water Cons. 50:460-463.

Frasier, G.W., M. Weltz, and L. Weltz. 1998a. Rainfall simulator runoff hydrograph analysis. J. Range Manage. 51:531-535.

Frasier, G.W., M.J. Trlica, W.C. Leininger, R.A. Pearce, and A. Fernald. 1998b. Runoff from simulated rainfall in 2 montane riparian communities. J. Range Manage. 51:315-322.

George, H.W. and R.C. Sidle. 1995. Geomorphic and pedologic influence on small-scale ephemeral channel dimension in rangelands. Water Resour. Bull: Amer. Water Res. Assoc. 31:1051-1062.

Hairsine, P.B. 1996. Comparing grass filter strips and near-natural riparian zones for trapping sediment and sorbed nutrients. ASSSI and NZSSS National Soils Conference, July 1996. 109 p.

Hairsine, P.B., C.J. Moran, and C.W. Rose. 1992. Recent developments regarding the influence of soil surface characteristics on overland flow and erosion. Aust. J. Soil Res. 30:249--264.

Hanson, C.L., A.R. Kuhlman, C.J. Erickson, and J.K. Lewis. 1970. Grazing effects on runoff and vegetation on western South Dakota rangeland. J. Range Manage. $23: 418-420$.

Kauffman, J.B., W.C. Krueger, and $M$. Vavra. 1983. Effects of late season cattle grazing on riparian plant communities. J. Range Manage. 36:685-690.

Laflen, J.M., L.J. Elliot, J.R. Simanton, C.S. Holzhey, and K.D. Kohl. 1991. WEPP Soil erodibility experiments for rangeland and cropland soils. J. Soil and Water Cons. 46:39-44.

Landry, M.S. and T.L. Thurow. 1997. Function and design of vegetation filter strips: An annotated bibliography. Texas State Soil and Water Cons.erv. Board Bull. No. 97-1. Temple, Tex. 67 p.
Lusby, G.C. 1970. Hydrologic and biotic effects of grazing versus non-grazing near Grand Junction, Colorado. USGS Prof. Pap. 700-B. U.S. Gov. Print. Off. Washington, D.C. $232-236$ p.

McEldowney, R.R. 1999. Montane riparian surface hydrology and sediment filtration as affected by cattle disturbance. M.S. Thesis. Colorado State Univ. Fort Collins, Colo.

Mohamoud, Y.M., L.K. Ewing, and C.W. Boast. 1990. Small plot hydrology: I. rainfall infiltration and depression storage determination. Trans. Amer. Soc. Agr. Eng. 33:1121-1131.

Mosley, M.P. 1972. An experimental study of rill erosion. M.S. Thesis. Colorado State Univ. Fort Collins, Colo.

Osborne, L.L. and D.A. Kovacic. 1993. Riparian vegetated buffer strips in waterquality restoration and stream management. Freshwater Bio. 29: 243-258.

Packer, P.E. 1953. Effects of trampling disturbance on watershed condition, runoff, and erosion. J. Forestry 51:28-31.

Pearce, R.A. 1995. Sediment movement and filtration within laboratory and riparian vegetation buffer strips. Ph.D. Diss. Colorado State Univ. Ft. Collins, Colo. 191 p.

Pearce, R.A., M.J. Trlica, W.C. Leininger, D.E. Mergen, and G. Frasier. 1998. Sediment movement through riparian vegetation under simulated rainfall and overland flow. J. Range Manage. 51:301-308.

Prosser, I.P., W.E. Dietrich, and J. Stevenson. 1995. Flow resistance and sediment transport by concentrated overland flow in a grassland valley. Geomorphology 13:71-86.

Renard, K.G., G.R. Foster, G.A. Weesies, D.K. McCool, and D.C. Yoder. 1997. Predicting Soil Erosion by Water: A Guide to Conservation Planning with the Revised Universal Soil Loss Equation (RUSLE). U.S. Dept. Agr., Agr. Handb. No. 703. U.S. Gov. Print. Off., Washington D.C. 404 p.

Roath, L.R. and W.C. Krueger. 1982. Cattle grazing influence on a mountain riparian zone. J. Range Manage. 35:100-103.

Rogers, R.D. and S.A. Schumm. 1991. The effect of sparse vegetation cover on erosion and sediment yield. J. Hydrol. 123:19-24.

Rogers, W.F. and V.P. Singh. 1986. Some geomorphic relationships and hydrograph analysis. Water Res. Bull. 22:777-784.

SAS ${ }^{\circledR}$. 1996. SAS System for Windows Version 6.12. Cary, N.C.

Schreiber, H.A. and D.R. Kincaid. 1967. Regression models for predicting on-site runoff from short-duration convective storms. Water Resour. Res. 3:389-395.

Schulz, T.T. and W.C. Leininger. 1990. Differences in riparian vegetation structure between grazed areas and exclosures. J. Range Manage. 43:295-299.

Schumm, S.A. and R.F. Hadley. 1959. Progress in the application of landform analysis in studies of semiarid erosion. Presentation at the Amer. Assoc. for the Advancement of Sci. Symp. on Quantitative Terrain Studies, Chicago, Ill. 14p.
Simanton, J.R., M.A. Weltz, and H.D. Larsen. 1991. Rangeland experiments to parameterize the water erosion prediction project model: vegetation canopy effects. J. Range Manage. 44:276-282.

Swanson, N.P. 1965. Rotating-boom rainfall simulator. Trans. Amer. Soc. Agr. Eng. 8:71-72.

Thurow, T.L., W.H. Blackburn, and C.A. Taylor, Jr. 1986. Hydrologic characteristics of vegetation types as affected by livestock grazing systems, Edwards Plateau, Texas. J. Range. Manage. 39:505-509.

USDA, Soil Conservation Service and Forest Service. 1980. Soil survey report. Larimer County area, Colorado. U.S. Gov. Print. Off. 239-812/48. Washington, D.C.

Warren, S.D., W.H. Blackburn, and C.A. Taylor, Jr. 1986. Effects of season and stage of rotation cycle on hydrologic condition of rangeland under intensive rotation grazing. J. Range Manage. 39:486-491.

Wheeler, M. A., M.J. Trlica, G.W. Frasier, and J.D. Reeder. 2002. Seasonal grazing affect soil physical properties of a montane riparian community. J. Range Manage. (Accepted) 